\title{
Growth performance and small intestinal morphology of native chickens after feed supplementation with tryptophan and threonine during the starter phase
}

\author{
Charles V. Lisnahan (D) and Oktovianus R. Nahak (iD) \\ Department of Animal Husbandry, Faculty of Agriculture, University of Timor, East Nusa Tenggara 85613, Indonesia. \\ Corresponding author: Charles V. Lisnahan, e-mail: charleslisnahan@yahoo.co.id \\ Co-author: ORN: oktovianusrafael@yahoo.co.id \\ Received: 24-08-2020, Accepted: 13-11-2020, Published online: 24-12-2020
}

doi: www.doi.org/10.14202/vetworld.2020.2765-2771 How to cite this article: Lisnahan CV, Nahak OR (2020) Growth performance and small intestinal morphology of native chickens after feed supplementation with tryptophan and threonine during the starter phase, Veterinary World, 13(12): 2765-2771.

\begin{abstract}
Background and Aim: The amino acid content of feed can affect growth performance of poultry during the first 6 weeks of life or the starter phase. Unlike for broiler and layer chickens, there is no information concerning standard requirements for tryptophan and threonine during the starter phase. This study aimed to determine the amount of threonine and tryptophan that should be supplemented in chicken feed to maximize growth performance and small intestinal morphology of native chickens during the starter phase.
\end{abstract}

Materials and Methods: A total of 128 day-old native chickens were divided into four treatment groups with four replications based on a completely randomized design. The treatment diets were as follows: $\mathrm{T}_{0}$ (control feed); $\mathrm{T}_{1}\left(\mathrm{~T}_{0}+0.10 \%\right.$ L-tryptophan $+0.35 \%$ L-threonine $) ; \mathrm{T}_{2}\left(\mathrm{~T}_{0}+0.17 \%\right.$ L-tryptophan $+0.68 \% \mathrm{~L}$-threonine $) ;$ and $\mathrm{T}_{3}\left(\mathrm{~T}_{0}+0.25 \% \mathrm{~L}\right.$-tryptophan $+1.00 \%$ L-threonine).

Results: The feed intake was highest for the $\mathrm{T}_{2}$ and $\mathrm{T}_{3}$ groups (123.06 and $124.18 \mathrm{~g} / \mathrm{bird} / \mathrm{week}$, respectively). The $\mathrm{T}_{3}$ group had the highest body weight gain $(49.35 \mathrm{~g} / \mathrm{bird} / \mathrm{week})$ and carcass weight $(201.44 \mathrm{~g} / \mathrm{bird})$ relative to the other groups, while the $\mathrm{T}_{2}$ and $\mathrm{T}_{3}$ groups showed similar, significant $(\mathrm{p}<0.05)$ increases in feed conversion ratio $(2.57$ and 2.51 , respectively) and carcass percentage (60.88 and $60.99 \%$ /bird, respectively) compared to the other groups. This study showed villi height, crypt depth, and villi width of duodenum, the highest jejunum and ileum of T3 $(1109.00 \pm 27.26,1325.50 \pm 75.00,1229.50 \pm 101.68$, $225.50 \pm 17.52,236.00 \pm 24.81,219.75 \pm 17.25,192.25 \pm 14.41,191.75 \pm 4.79$, and $184.75 \pm 6.40$, respectively) compare to other treatment.

Conclusion: These results indicate that supplementation of feed with $0.17 \%$ L-tryptophan and $0.68 \%$ L-threonine positively affected the growth performance and small intestinal morphology of native chickens during the starter phase.

Keywords: growth performance, native chickens, small intestinal morphology, starter phase, threonine, tryptophan.

\section{Introduction}

Protein in the starter phase (0-6 weeks of age) is critical for the survival of native chickens. Amino acids as a constituent of proteins play roles in the growth and physiological functions of chickens. Micronutrients, especially balanced amino acids, can promote maximum growth in native chickens. Protein derived from fish and soybean meal included in diets for native chickens can be very expensive. For economical supplementation to address deficiencies in specific amino acids in poultry feed, synthetic amino acids have been added to chicken feed, particularly beginning in the early 1990s.

In a previous study, Lisnahan et al. [1] showed that growth performance and feed efficiency of starter phase native chickens could be improved by the

Copyright: Lisnahan and Nahak. Open Access. This article is distributed under the terms of the Creative Commons Attribution 4.0 International License (http://creativecommons.org/licenses/ by/4.0/), which permits unrestricted use, distribution, and reproduction in any medium, provided you give appropriate credit to the original author(s) and the source, provide a link to the Creative Commons license, and indicate if changes were made. The Creative Commons Public Domain Dedication waiver (http:// creativecommons.org/publicdomain/zero/1.0/) applies to the data made available in this article, unless otherwise stated. addition of the critical amino acids methionine and lysine. Threonine and tryptophan are two other limiting amino acids in chicken diets. Threonine is involved in bone formation and a variety of physical systems, including the immune, nervous and digestive systems, and the liver. This amino acid also is important for maintaining protein levels and fat metabolism [2]. Tryptophan is a serotonin trigger that stimulates niacin production, appetite, and feed efficiency and also promotes increases in body weight $[3,4]$.

Unlike for broiler and layer chickens, there is no information concerning standard requirements for tryptophan and threonine during the starter phase. This study aimed to determine the amount of threonine and tryptophan that should be supplemented in chicken feed to maximize growth performance and small intestinal morphology of native chickens during the starter phase.

\section{Materials and Methods}

\section{Ethical approval}

The study protocol was approved by Animal Ethics Committee of the Animal Husbandry Program Study, Agriculture Faculty, Timor University, Indonesia. 
Study period, location, Animal, and feed preparation

This study was conducted in Kefamenanu in the East Nusa Tenggara province of Indonesia between February 2020 and April 2020. A total of 128 day-old chicks hatched in Kefamenanu, East Nusa Tenggara and weighing on average $34 \mathrm{~g}$ were used in the study. Chicks were vaccinated at 3 and 21 days old with ND1 and ND2 vaccines, respectively. Feed was obtained from farmers, with the exception of fish meal, soybean meal, amino acids, and vitamin and mineral premixes, which were purchased from a poultry shop. The cage units used were $100 \mathrm{~cm} \times 100 \mathrm{~cm} \times 70 \mathrm{~cm}$ and 16 individual cages were contained within a larger cage that was $6 \mathrm{~m} \times 9 \mathrm{~m} \times 5 \mathrm{~m}$. Each cage unit had eight chickens.

\section{Dietary treatment and feeding duration}

Chicks were randomly assigned to one of four groups in a completely randomized design (CRD) experiment involving four treatments: $\mathrm{T}_{0}$ (control feed $), \mathrm{T}_{1} \quad\left(\mathrm{~T}_{0}+0.10 \% \quad\right.$ L-tryptophan $+0.35 \%$ L-threonine, $\mathrm{T}_{2} \quad\left(\mathrm{~T}_{0}+0.17 \% \quad\right.$ L-tryptophan $+0.68 \%$ L-threonine), and $\mathrm{T}_{3}\left(\mathrm{~T}_{0}+0.25 \%\right.$ L-tryptophan $+1.00 \%$ L-threonine). The feed ingredients and nutrient composition of each treatment are shown in Table-1. Feed and water were available ad libitum during the study period. Feed was given every morning and evening. Feed was weighed daily and chickens were weighed weekly. After 6 weeks, the chickens were sacrificed and the carcass weight and small intestinal morphology were determined for 32 birds.

\section{Small intestinal morphology measurement}

The small intestinal morphology measurement comprise was villi height, villi width, and crypt depth. Villi height, villi width, and crypt depth are measured in stages:

\section{Chicken intestinal sample preparation}

The small intestinal segments prepared as samples are the duodenum, jejunum, and ileum. Each part was taken $2 \mathrm{~cm}$ pieces and fixed in $10 \%$ buffer formalin, soaked for 24-48 h, and then made preparations.

\section{Preparation making}

The way of making hematoxylin-eosin preparations, each piece of tissue is hydrated through a series of alcohol whose concentration is increasing $(70,80$, 90, and 95\%). The samples were transferred one by one to each alcohol concentration and allowed to soak for about $10 \mathrm{~s}$. Then, the sample is inserted into xylol and finally immersed in paraffin. The sample was sliced thin using a microtome for hematoxylin-eosin staining. The histological preparations that were ready in the glazed object were observed and measured using a computer microscope.

\section{Shooting}

The object of the sample was viewed and determined using an Olympus BX 51 microscope equipped with an Olympus DP 12 projector adjusted to 10 times magnification. Morphological images appeared on the JVC TMH $1750 \mathrm{C}$ monitor. After finding the intestinal morphology as expected, all the preparations to be measured were taken. Minimum measurements of 3 times per slide are made for parameters.

\section{Measurement steps for villi height, villi width, and depth of Lieberkuhn crypt}

The measurements of villi height, villi width, and depth of Lieberkuhn crypt were done using a flat screen computer with the Microsoft Office Picture Manager program at $40 \%$ magnification. At first, the

Table-1: Composition (\%) and nutrient content (\% dry matter) of experimental diets during the starter phase (1-6 weeks).

\begin{tabular}{|c|c|c|c|c|}
\hline \multirow[t]{2}{*}{ Ingredients } & \multicolumn{4}{|c|}{ Treatments (\%) } \\
\hline & $\mathbf{T}_{0}$ & $\mathbf{T}_{1}$ & $\mathbf{T}_{2}$ & $\mathbf{T}_{3}$ \\
\hline Yellow corn & 55.00 & 55.00 & 55.00 & 55.00 \\
\hline Rice bran & 28.20 & 27.75 & 27.35 & 26.95 \\
\hline Soybean meal & 8.00 & 8.00 & 8.00 & 8.00 \\
\hline Fish meal & 7.00 & 7.00 & 7.00 & 7.00 \\
\hline Mineral premix & 0.40 & 0.40 & 0.40 & 0.40 \\
\hline Vitamin premix & 0.34 & 0.34 & 0.34 & 0.34 \\
\hline DI-methionine & 0.27 & 0.27 & 0.27 & 0.27 \\
\hline L-lysine $\mathrm{HCl}$ & 0.79 & 0.79 & 0.79 & 0.79 \\
\hline L-tryptophan & 0 & 0.10 & 0.17 & 0.25 \\
\hline L-threonine & 0 & 0.35 & 0.68 & 1.00 \\
\hline Total & 100.00 & 100.00 & 100.00 & 100.00 \\
\hline \multicolumn{5}{|l|}{ Calculated nutrient content (\%) } \\
\hline Metabolized energy (kcal/kg) & 2962.85 & 2952.82 & 2943.92 & 1935.87 \\
\hline Crude protein & 16.75 & 16.72 & 16.68 & 16.65 \\
\hline Ether extract & 6.01 & 5.97 & 5.94 & 5.90 \\
\hline Ash & 8.08 & 8.04 & 8.00 & 7.96 \\
\hline Crude fiber & 6.97 & 6.91 & 6.85 & 6.79 \\
\hline Methionine & 0.30 & 0.30 & 0.30 & 0.30 \\
\hline Lysine & 0.85 & 0.85 & 0.85 & 0.85 \\
\hline Tryptophan & 0.03 & 0.13 & 0.20 & 0.28 \\
\hline Threonine & 0.05 & 0.40 & 0.72 & 1.05 \\
\hline Calcium & 1.62 & 1.62 & 1.62 & 1.62 \\
\hline Phosphorus available & 0.58 & 0.58 & 0.58 & 0.58 \\
\hline
\end{tabular}


standard size of $\mu \mathrm{m}$ is determined with the help of a computer, namely, how much the magnification value used or desired is converted into units of length $(\mu \mathrm{m})$. The $\mu \mathrm{m}$ unit number obtained was then used as a standard in measuring the villi height, villi width, and the depth of the crypt displayed on the monitor screen.

\section{Data collection and analysis}

Several parameters of native chickens were measured including feed intake, body weight gain, feed conversion, carcass weight, and carcass percentage. Bodyweight gain was the difference in weight between the final body weight and the initial body weight. The feed conversion ratio is calculated based on weight gain divided by feed intake. Carcass weight was obtained after being reduced by blood, feathers, head and neck, shank, internal organs, and abdominal fat. The small intestinal morphology observed was villi height, crypt depth, and villi width of duodenum, jejunum, and ileum. The data were subjected to an analysis of variance based on the CRD and Duncan's test (IBM SPSS Statistics 22).

\section{Results}

\section{Body weight gain}

Statistical analysis showed significant increases in body weight for all experimental groups during the starter phase $(\mathrm{p}<0.05$; Table- 2$)$. The average weight gain was highest for the $\mathrm{T}_{3}$ group $(0.25 \%$ L-tryptophan and $1.00 \%$ L-threonine) followed by the $\mathrm{T}_{2}(0.17 \%$ L-tryptophan and $0.68 \%$ L-threonine) and $\mathrm{T}_{1}$ group $(0.10 \%$ L-tryptophan and $0.35 \%$ L-threonine), whereas birds in the $\mathrm{T}_{0}$ group (no amino acid supplementation) gained the least weight (Figure-1). The $\mathrm{T}_{2}$ and $\mathrm{T}_{3}$ groups had similar percentages of body weight gain, 6.60 and $6.69 \%$, respectively. The highest rate of weight gain for native chickens was seen for the $\mathrm{T}_{3}$ group at $49.35 \pm 0.97 \mathrm{~g} / \mathrm{bird} / \mathrm{week}$, but this increase did not significantly from that seen for the $\mathrm{T}_{2}$ group $(47.87 \pm 1.15 \mathrm{~g} / \mathrm{bird} /$ week $)$.

\section{Feed intake}

Native chickens had significant feed intake during the starter phase $(p<0.05$; Table-2). The average feed consumption was highest for the $\mathrm{T}_{3}$ group followed by the $T_{2}$ and $T_{1}$ groups. The $T_{0}^{3}$ group with no supplementation consumed the least feed (Figure-2). Supplementation with the lowest levels of L-tryptophan and L-threonine in the $\mathrm{T}_{1}$ group was associated with an increase of $6.21 \%$ relative to the $T_{0}$ group, and the intake increased by another $5.57 \%$ for the $\mathrm{T}_{2}$. A slight, but not significant, increase over that for $T_{2}^{2}$ was seen for $T_{3}$.

\section{Feed conversion ratio}

Differences in the feed conversion ratio of native chickens at the beginning of the starter phase were not significant (Figure-3). The average conversion of native chicken feed was highest for birds in the $\mathrm{T}_{0}$ treatment group, followed by those in $\mathrm{T}_{1}, \mathrm{~T}_{2}$, and $\mathrm{T}_{3}$ groups, respectively (Table-2 and Figure-3). This result suggests that tryptophan and threonine supplementation does not affect the feed conversion ratio during the starter phase.

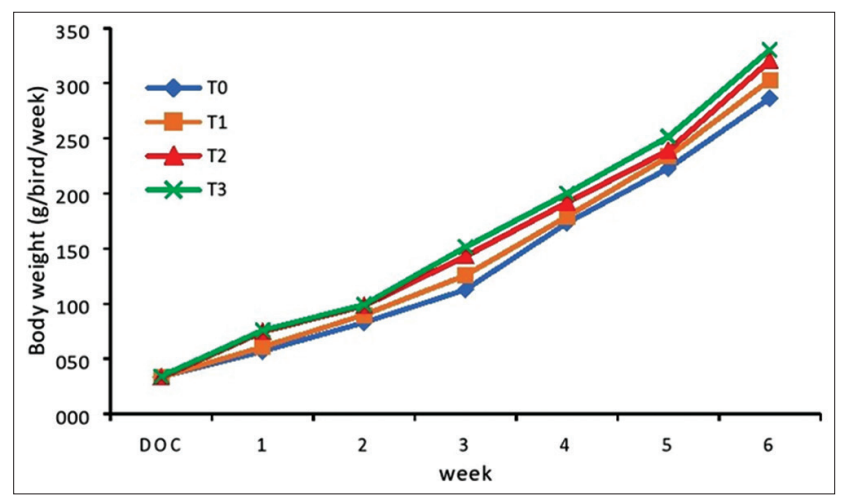

Figure-1: Relationship between diet treatment and body weight of native chickens during the starter phase (1-6 weeks).

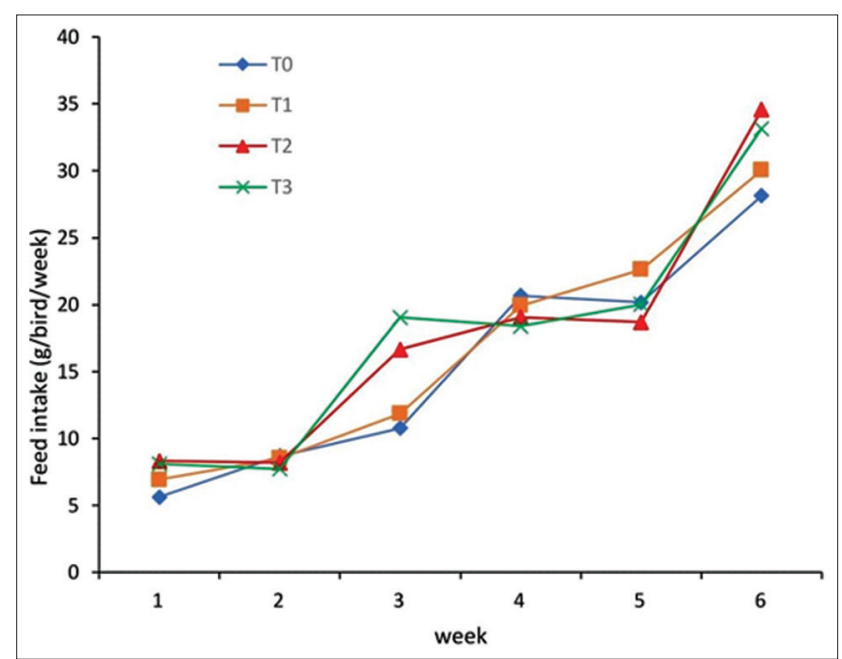

Figure-2: Relationship between diet treatment and feed intake of native chickens during the starter phase (1-6 weeks).

Table-2: Growth performance of native chickens during the starter phase (1-6 weeks).

\begin{tabular}{lcccc}
\hline Parameters & \multicolumn{3}{c}{ Treatments } \\
\cline { 2 - 5 } & $\mathbf{T}_{\mathbf{0}}$ & $\mathbf{T}_{\mathbf{1}}$ & $\mathbf{T}_{\mathbf{2}}$ & $\mathbf{T}_{\mathbf{3}}$ \\
\hline Feed intake (g/bird/week) & $109.75 \pm 4.43^{\mathrm{c}}$ & $116.57 \pm 4.93^{\mathrm{b}}$ & $123.06 \pm 4.01^{\mathrm{a}}$ & $124.18 \pm 3.09^{\mathrm{a}}$ \\
Body weight gain (g/bird/ week) & $42.09 \pm 1.67^{\mathrm{c}}$ & $44.87 \pm 2.18^{\mathrm{b}}$ & $47.87 \pm 1.15^{\mathrm{a}}$ & $49.35 \pm 0.97^{\mathrm{a}}$ \\
Feed conversion ratio & $2.61 \pm 0.11$ & $2.60 \pm 0.02$ & $2.57 \pm 0.02$ & $2.52 \pm 0.06$ \\
Carcass weight (g/bird) & $167.02 \pm 5.47^{\mathrm{c}}$ & $181.88 \pm 6.01^{\mathrm{b}}$ & $195.04 \pm 5.20^{\mathrm{a}}$ & $201.44 \pm 3.55^{\mathrm{a}}$ \\
Percent carcass (\%/bird) & $58.31 \pm 0.83^{\mathrm{b}}$ & $60.05 \pm 0.33^{\mathrm{a}}$ & $60.88 \pm 0.80^{\mathrm{a}}$ & $60.99 \pm 0.66^{\mathrm{a}}$ \\
\hline
\end{tabular}

$a, b, c, d$ Different superscript on the same line indicates significant difference $(p<0.05)$ 


\section{Carcass weight}

The carcass weight of native chickens showed significant differences among the treatment groups $\left(\mathrm{p}<0.05\right.$; Table-2). Birds in the $\mathrm{T}_{3}$ group had the highest carcass weight and percentage, followed by the $\mathrm{T}_{2}, \mathrm{~T}_{1}$, and $\mathrm{T}_{0}$ groups. The $\mathrm{T}_{1}$ group showed an $8.89 \%$ increase in carcass weight over that for the $\mathrm{T}_{0}$ group. Further increases in the amount of tryptophan and threonine supplementation increased the carcass weight by another $3.35 \%$ for the $\mathrm{T}_{2}$ group, which was similar to that for the $\mathrm{T}_{3}$ group.

\section{Small intestinal morphology}

The villi height, depth of crypt, and villi width of duodenal, jejunum, and ileum are presented in Table-3. The data showed that the villi height, crypt depth, and the villi width of the duodenal, jejunum, and ileum at the end of the starter phase of native chickens (6 weeks) were significantly different $(\mathrm{P}<0.05)$. Supplementation of $0.10 \%$ 1-tryptophan and $0.35 \%$ 1-threonine $\left(\mathrm{T}_{1}\right)$ increased the duodenal and ileum villi height by $11.93 \%$ and $21.15 \%$ compared to $\mathrm{T}_{0}$. At the $0.17 \%$ l-tryptophan and $0.68 \%$ l-threonine $\left(\mathrm{T}_{2}\right)$ levels, there was an increase in villi height in the duodenum, jejunum, and ileum by $5.97 \%, 17.80 \%$, and $22.79 \%$ compared to T1. When increased at the $0.25 \%$ 1-tryptophan and 1.00\% 1-threonine levels, duodenal villi height increased by $7.77 \%$ compared to $\mathrm{T}_{2}$.

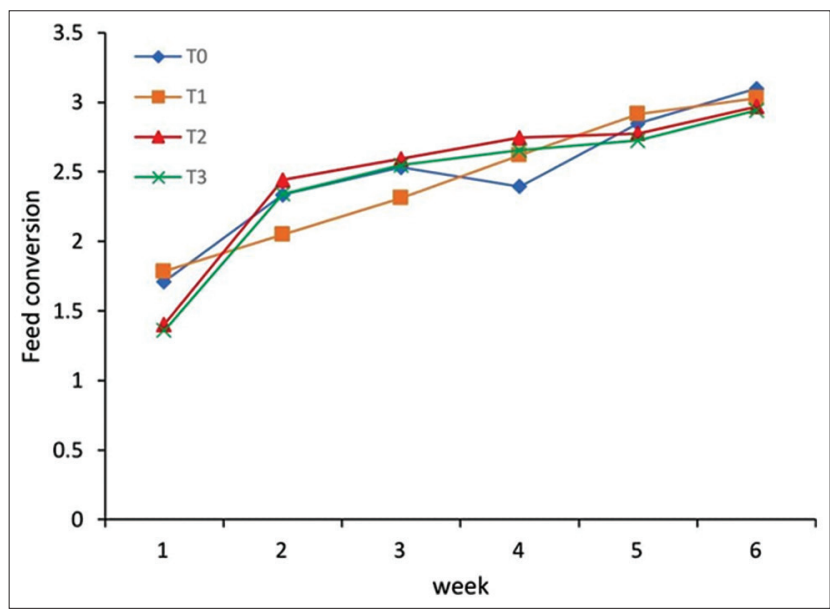

Figure-3: Relationship between diet treatment and feed conversion ratio of native chickens during the starter phase (1-6 weeks).
Supplementation of $0.10 \%$ 1-tryptophan and $0.35 \%$ 1-threonine $\left(\mathrm{T}_{1}\right)$ increased the ileum crypt depth by $23.65 \%$ compared to $\mathrm{T}_{0}$. When increased at the level of $0.17 \%$ l-tryptophan and $0.68 \%$ 1-threonine $\left(\mathrm{T}_{2}\right)$, there was an increase in the crypt depth of the duodenal by $13.31 \%$ compared to $\mathrm{T}_{1}$. At the level of $0.25 \%$ 1-tryptophan and $1.00 \%$ 1-threonine, the crypt depth of jejunum increased by $18.15 \%$ compared to $\mathrm{T} 1$, while for ileum, there was an increase of $5.90 \%$ compared to $\mathrm{T}_{2}$.

Supplementation of $0.10 \%$ l-tryptophan and $0.35 \%$ l-threonine $\left(\mathrm{T}_{1}\right)$ increased the villi width of the duodenal, jejunum, and ileum by $12.50 \%, 14.92 \%$, and $19.80 \%$ compared to $T_{0}$. Changes in the villi width of the jejunum and ileum also occurred at the level of $0.17 \%$ 1-tryptophan and $0.68 \%$ 1-threonine $\left(\mathrm{T}_{2}\right)$ of $15.75 \%$ and $17.55 \%$ compared to T1. At the $0.25 \%$ 1-tryptophan and 1.00\% 1-threonine level, the duodenal villi width increased by $32.56 \%$ compared to $\mathrm{T} 2$, while the jejunum and ileum were not significant.

\section{Discussion}

Feed supplementation with L-tryptophan and L-threonine increased the body weight of native chickens. In a previous study, Lisnahan et al. [1] reported that 6-week-old native chickens had an average weight of $284.61 \mathrm{~g} /$ bird when given feed supplemented with Dl-methionine and L-lysine, but lacking L-tryptophan and L-threonine. In the present study, birds given a diet supplemented with $0.25 \%$ L-tryptophan and $0.85 \%$ L-threonine had an average body weight of $330.29 \mathrm{~g} / \mathrm{bird}$. For chickens, after methionine and lysine, threonine and tryptophan are the next most critical amino acids $[3,5]$.

Opoola et al. [5] showed that the addition of 0.23 $0.31 \%$ tryptophan to feed increased the body weight of broiler chickens, whereas Wei et al. [6] reported that broiler chicken weight gain could be achieved by the addition of $0.23 \%$ tryptophan in feed under feed restriction. Threonine and tryptophan supplementation not only increases body weight, but also accelerates growth to maximize growth of chickens. Cafe and Waldroup [7] found that chicken body weight could be influenced by the availability and balance of amino acids in the feed. In addition to methionine and lysine,

Table-3: Average of small intestine morphology size of native chickens at 6 weeks age.

\begin{tabular}{|c|c|c|c|c|c|}
\hline \multirow{2}{*}{$\begin{array}{l}\text { Characteristic of } \\
\text { intestine }\end{array}$} & \multirow[t]{2}{*}{ Small intestine part } & \multicolumn{4}{|c|}{ Treatments } \\
\hline & & $\mathbf{T}_{0}$ & $\mathbf{T}_{1}$ & $\mathbf{T}_{2}$ & $\mathbf{T}_{3}$ \\
\hline \multirow[t]{3}{*}{ Villi height } & Duodenum & $867.50 \pm 44.36^{d}$ & $971.00 \pm 14.45^{c}$ & $1029.50 \pm 26.94^{a, b}$ & $1109.00 \pm 27.26^{a}$ \\
\hline & Jejunum & $989.50 \pm 42.05^{b}$ & $1069.00 \pm 42.15^{b}$ & $1259.25 \pm 154.14^{\mathrm{a}}$ & $1325.50 \pm 75.00^{\mathrm{a}}$ \\
\hline & Ileum & $766.00 \pm 11.62^{c}$ & $928.00 \pm 41.59^{b}$ & $1139.50 \pm 130.16^{a}$ & $1229.50 \pm 101.68^{a}$ \\
\hline \multirow[t]{3}{*}{ Crypt depth } & Duodenum & $166.00 \pm 16.02^{\mathrm{b}}$ & $186.00 \pm 13.51^{\mathrm{b}}$ & $210.75 \pm 12.66^{a}$ & $225.50 \pm 17.52^{\mathrm{a}}$ \\
\hline & Jejunum & $177.00 \pm 4.69^{c}$ & $199.75 \pm 6.95^{\mathrm{b}, \mathrm{c}}$ & $220.25 \pm 16.98^{a, b}$ & $236.00 \pm 24.81^{a}$ \\
\hline & Ileum & $143.75 \pm 4.92^{c}$ & $177.75 \pm 6.29^{b}$ & $207.50 \pm 13.28^{a, b}$ & $219.75 \pm 17.25^{a}$ \\
\hline \multirow[t]{3}{*}{ Villi width } & Duodenum & $136.00 \pm 9.83^{c}$ & $153.00 \pm 11.04^{b}$ & $169.00 \pm 4.24^{a, b}$ & $192.25 \pm 14.41^{\mathrm{a}}$ \\
\hline & Jejunum & $134.00 \pm 5,60^{c}$ & $154.00 \pm 15.38^{b}$ & $178.25 \pm 6.13^{a}$ & $191.75 \pm 4.79^{a}$ \\
\hline & Ileum & $122.50 \pm 5.07^{c}$ & $146.75 \pm 15.11^{b}$ & $172.50 \pm 3.70^{\mathrm{a}}$ & $184.75 \pm 6.40^{\mathrm{a}}$ \\
\hline
\end{tabular}

$\overline{a, b, c, d}$ Different superscript on the same line indicates significant difference $(p<0.05)$ 
threonine and tryptophan play roles in metabolic and physiological functions [3,8]. Wen et al. [9] suggested that threonine, lysine, methionine, valine, and isoleucine are important muscle components and deficiencies in these amino acids are always associated with reduced weight. High levels of tryptophan positively affected systemic immune responses and growth performance in poultry $[10,11]$. Meanwhile, niacin-deficient poultry feed affects the action of tryptophan by ameliorating weight gain and modulating feed consumption [12].

Feed intake and body weight are influenced by threonine $[13,14]$, while tryptophan regulates protein biosynthesis and, in particular, is involved in increasing muscle mass and stimulating immune responses. Tryptophan can promote stability of intracellular proteins that contribute to enhanced growth and antibody production. In addition, tryptophan is a precursor of serotonin that is involved in mental function $[3,15,16]$. Studies by Wei et al. [6] and Duarte et al. [17] showed that tryptophan is indeed important for protein synthesis and as a serotonin precursor that stimulates feed intake. In poultry, tryptophan is converted into 5-hydroxytryptophan molecules that play a role in production of both serotonin and melatonin in the brain to control stress and increase metabolism [18]. Wen et al. [9] showed that feed consumption, behavior, growth, immunity, protein synthesis, and intestinal integrity of livestock can be regulated by tryptophan supplementation. Tryptophan is prominent among essential amino acids due to these critical roles in protein synthesis and serotonin production that together stimulate feed consumption and promote growth [17].

L-threonine supplementation enhances immunity, antioxidant capacity, and intestinal health of broilers in the starter phase. In particular, immunoglobulins, including immunoglobulin A (IgA), immunoglobulin G, and secreted IgA involved in immune responses and alleviation of stress are affected by threonine levels [13,19]. Rezaeipor et al. [20] reported that threonine improved the morphological characteristics of the small intestinal in broiler chickens and these characteristics are reflected by an increased growth rate. Chickens fed a diet deficient in threonine have reduced nutrient absorption in the digestive tract. Estalkhzir et al. [13] and Azzam et al. [21] also showed that threonine is important for maintaining mucosal stability in the digestive tract that leads to increased appetite, digestion, and nutrient absorption that translate to increased body weight. Lisnahan and Nahak [4] and Ahmadi and Golian [22] demonstrated that threonine affects bone formation and plays multiple roles in immune system function and fat metabolism, as well as various physiological systems, including the liver, nervous system, and digestive tract.

Native chickens given feed with L-tryptophan and L-threonine supplementation had increased body weight and feed consumption compared to birds without supplementation. Lisnahan et al. [1] reported that during the starter phase (0-6 weeks), feed conversion decreased with increasing levels of methionine and lysine in feed. Here, we observed no effect of L-tryptophan and L-threonine through the starter phase. However, the feed conversion ratio tended to be higher for native chickens given feed supplemented with L-tryptophan and L-threonine relative to unsupplemented feed (Figure-3). This result suggests that feed conversion is impacted by threonine and tryptophan. Feed conversion is influenced by genetics, type of feed, and feed additives used, in addition to livestock management methods and environmental factors such as temperature [23]. Threonine and tryptophan supplementation balances dietary amino acids to optimize amino acid ratios and protein content of feed that together can reduce the amount of added protein, which can be expensive, needed to maximize growth gains of poultry.

Carcass weight correlates to body weight. Tamzil [24] reported that the percentage of native chicken carcass at the end of the starter phase (6 weeks) was $61.39 \%$. Adequate amounts and the balance of amino acid in feed consumed by chickens can affect the production performance and feed use efficiency $[1,25]$. Important metabolic processes such as uric acid formation and protein synthesis involve threonine [21]. Suryawan et al. [26] reported that the increase in carcass weight was influenced by the rate of formation of new tissue compared to the rate of tissue damage. Tryptophan and threonine are both important for protein synthesis and increased muscle mass to increase body weight, especially muscles that comprise the carcass $[15,16]$.

Kidd and Hackenhaar [27] found that tryptophan deficiency not only affects carcass quality by affecting protein synthesis but also impairs the synthesis of important neurotransmitters such as serotonin and melatonin. Leeson and Summers [28] reported that amino acid availability in chicken feed affects growth, production, and efficiency of feed use that is related to tissue formation and, in turn carcass weight. Furthermore, Zhai et al. [29] stated that the addition of lysine in feed and several amino acids in the form of soluble protein enhanced the water retention capacity and $\mathrm{pH}$ of breast meat, while also reducing protein denaturation and increasing levels of methionine and threonine. Thus, lysine and, in particular, threonine are important for the formation of breast meat, which represents a major component of the carcass [30].

The increase of villi size (height, crypt depth, and villi width) was positively correlated with feed consumption and growth (Table-2). Chicken growth depends on digestion and absorption of nutrients related to the morphological and functional development of the small intestine. An increase of villi size is associated with an increase in digestive function for nutrient absorption. Awad et al. [31] stated that the increase of villi height in the chicken intestine is 
parallel to the increase of digestive and absorption functions as well as a smooth expression of the nutrient transport system throughout the body.

Increasing crypt depth causes absorption of more nutrients into the bloodstream, causing the increasing of growth and efficiency of feed used to be better. It can also be seen that at T3, body weight gain and feed consumption are better. Sun et al. [32] stated that the development of chicken intestinal villi is related to intestinal function and growth of the chicken. The ability to digest and absorb nutrients is influenced by the surface area of the intestinal epithelium, the number of folds, and the number of villi and microvilli that expand the absorption field [31]. As a result, the development of the digestive tract, including the intestine is also better. The size of the intestine is larger and longer (number, height, and width of the villi) as a place for better absorption of nutrients into all body tissues. Fitasari [33] stated that one of the parameters that can be used to measure the quality of growth is the intestinal morphological structure. The intestinal villi are a place for absorption of nutrients, the wider the villi the more nutrients are absorbed which ultimately has an impact on the growth of the body's organs. Awad et al. [31] stated that an increase in the height and width of the villi in chicken intestines is closely related to an increase in digestive function and absorption function due to the wider absorption area and is an expression of the smooth transportation system for nutrients throughout the body's tissues. Chickens are given amino acids which can improve digestibility in the ileum and can also increase the digestibility of other amino acids such as isoleucine, phenylalanine, valine, aspartic acid, and tyrosine [34].

Azzam et al. [19] stated that threonine increases humoral immune response by increasing globulin levels and antioxidant levels in chickens. In addition, threonine helps maintain the integrity of the intestinal mucosal barrier and thus improves nutrient absorption. Azzam et al. [21] and Estalkhzir et al. [13] found that adding threonine to the diet of broilers increased productivity in terms of body weight, feed conversion, relative breast weight, and thigh weight. Among the essential amino acids, threonine plays an important role in the maintenance of intestinal barrier integrity and mucin synthesis $[20,35,36]$.

\section{Conclusion}

Feed intake, body weight gain, carcass weight, carcass percentage, villi height, crypt depth, and villi width of small intestine of native chickens during the starter phase were increased by supplementation with feed containing increasing amounts of L-threonine and L-tryptophan. In particular, supplementation with 0.17 L-tryptophan and $0.68 \%$ L-threonine produced optimal growth performance of native chickens during the starter phase.

\section{Authors' Contributions}

CVL compiled the experiment ideas and designed the work, collected the data, supervised the work, analyzed the data, and drafted the manuscript. ORN designed the work, the laboratory work, and supervised the work. CVL and ORN revised and agreed to the final manuscript. All authors read and approved the final manuscript.

\section{Acknowledgments}

The authors gratefully acknowledge funding support from a "Basic Research Grant" (No. 7/E/KTP/2019) provided by The Directorate General of Research and Development Strengthening, Ministry of Research, Technology, and Higher Education, Indonesia.

\section{Competing Interests}

The authors declare that they have no competing interests.

\section{Publisher's Note}

Veterinary World remains neutral with regard to jurisdictional claims in published institutional affiliation.

\section{References}

1. Lisnahan, C.V., Wihandoyo, Zuprizal, and Harimurti, S. (2017) Effect of addition of methionine and lysine into diets based on cafeteria stabdars on the growth performance of native chickens at starter phase. Int. J. Poult. Sci., 16(12): 506-510.

2. Chen, Y.P., Cheng, Y.F., Li, X.H., Yang, W.L., Wen, C., Zhuang, S. and Zhou, Y.M. (2017) Effects of threonine supplementation on the growth performance, immunity, oxidative status, intestinal integrity and barrier function of broilers at the early age. Poult. Sci., 96(2): 405-413.

3. Qaisrani, S.N., Ahmed, I., Azam, F., Bibi, F., Saima, Pasha, T.N. and Azam, F. (2018) Threonine in broiler diets: An updated review. Ann. Anim. Sci., 18(3): 659-674.

4. Lisnahan, C.V. and Nahak, O.R. (2019) Effects of L-threonine and L-tryptophan supplementation on growth performance of native chickens during the grower phase. Int. J. Poult. Sci., 18(12): 570-575.

5. Opoola, E., Onimisi, P.A., Ogundipe, S.O. and Bawa, G.S. (2017) Effect of dietary tryptophan levels on growth performance of broiler chickens reared in the hot season under tropical environment. Trop. Subtrop. Agroecosyst., 20(3): 429-437.

6. Wei, Z., Wang, Y.L., Ji, Y., Hu, L.H., Pan, X.H., Wang, M.Z. and Wang, H.H. (2011) Effects of dietary tryptophan supplementation and feed restriction on growth performance and carcass characteristics of goslings. J. Anim. Vet. Adv., 10(16): 2019-2083.

7. Cafe, M.B. and Waldroup, P.W. (2006) Interactions between levels of methionine and lysine in broiler diets changed at typical industry intervals. Int. J. Poult. Sci., 5(11): 1008-1015

8. NRC. (1994) National Research Council: Nutrient Requirement of Poultry. $8^{\text {th }}$ ed. National Academy Press, Washington, D.C.

9. Wen, H., Feng, L., Jiang, W., Liu, Y., Jiang, J., Li, S., Tang, L., Zhang, Y., Kuang, S. and Zhou, X. (2014) Dietary tryptophan modulates intestinal immune response, barrier function, antioxidant status and gene expression of TOR and Nrt2 in young grass carp (Ctenopharyngodon idella). Fish Shellfish Immunol., 40(1): 275-287.

10. Emadi, M.F., Jahanshiri, K., Kaveh, K., Bejo, M.H., 
Ideris, A. and Alimon, R. (2010) Tryptophan stimulates immune response in broiler chickens challenged with infectious bursal disease vaccine. J. Anim. Vet. Adv., 9(3): 610-616.

11. Preedaa, M.G., Selvaraj, P., Visha, P., Purushothaman, M.R. and Murali, N. (2017) Effect of dietary tryptophan supplementation on blood biochemical parameters in layer chicken. Int. J. Curr. Microbiol. Appl. Sci., 6(7): 1445-1452.

12. Xie, J., Tang, L., Lu, L., Zhang, L., Xi, L., Liu, H.C., Odle, J. and Luo, X. (2014) Differential expression of heat shock transcription factors and heat shock proteins after acute and chronic heat stress in laying chickens (Gallus gallus). PLoS One, 9(7): 1-9.

13. Estalkhzir, F.M., Khojasteh, S. and Jafary, M. (2013) The effect of different levels of threonine on performance and carcass characteristics of broiler chickens. J. Nov. Appl. Sci., 2(9): 382-386.

14. Al-Hayani, W.K.A. (2017) Effect of threonine supplementation on broiler chicken productivity traits. Int. J. Poult. Sci., 16(4): 160-168.

15. Younis, M.E., El-Edel, M.A., Nasr, S.M., Mahrous, U.E. and Aboghanima, M.M. (2016) Response of Cobb and Sasso broilers to feeding restriction and tryptophan supplementation. Alex. J. Vet. Sci., 51(1): 127-134.

16. Hoseini, S.M., Jimenez, A.P., Costas, B., Azeredo, R. and Gesto, M. (2019) Physiological roles in teleosts: Current knowledge and perspectives for future studies. Rev. Aquac., 11(1): 3-24.

17. Duarte, K.F., Junqueira, O.M., Filardi, R.S., Siqueira, J.C., Puzotti, M.M., Garcia, E.A., Molino, A.B. and Laurentiz, A.C. (2013) Disgestible tryptophan requirements for broilers from 22 to 42 days old. Rev. Bras. Zootec., 42(10): 728-733.

18. Shan, A.S., Sterling, K.G., Pesti, G.M., Bakalli, R.I., Driver, G.P. and Tejedor, A.A. (2003) The influence of temperature on the threonine and tryptophan requirements of young broiler chicks. Poult. Sci., 82(7): 1154-1162.

19. Azzam, M.M.M., Zou, X.T., Dong X.Y. and Xie, P. (2011) Effect of supplemental L-threonine on mucin 2 gene expression and intestine mucosal immune and digestive enzymes activities of laying hens in environments with high temperature and humidity. Poult. Sci., 90(10):2251-2256.

20. Rezaeipor, V., Fononi, H. and Irani, M. (2012) Effects of dietary L-threonine and Saccharomyces cerevisiae on performance, intestinal morphology and immune response of chickens. S. Afr. J. Anim. Sci., 42(3): 266-273.

21. Azzam, M.M.M. and El-Gogary, M.R. (2015) Effect of dietary threonine levels and stocking destiny on the performance, metabolic status and immunity of broiler chickens. Asian J. Anim. Vet. Adv., 10(5): 215-225.

22. Ahmadi, H. and Golian, A. (2010) The integration of broiler chicken threonine responses data into neural network models. Poult. Sci., 89(11): 2535-2541.

23. James, R.G. (2004) Modern Livestock and Poultry Production. $7^{\text {th }}$ ed. Thomson Delmar Learning Inc., FFA Activities, London.

24. Tamzil, M.H. (2014) Heat stress on poultry: Metabolism, effects and efforts to overcome. Wartazoa, 24(2): 57-66.

25. Pesti, G.M., Bakalli, R.I., Driver, J.P., Atencio, A. and Foster, E.H. (2005) Poultry Nutrition and Feeding. The University of Georgia, Department of Poultry Science, Trafford Publishing, Athens.

26. Suryawan, A., O’Connor, P.M., Bush, J.A., Nguyen, H.V. and Davis, T.S. (2009) Differential regulation of protein synthesis by amino acids and insulin in peripheral and visceral tissues of neonatal pigs. Amino Acids, 37(1): 97-104.

27. Kidd, M.T. and Hackenhaar, L. (2006) Dietary threonine for broilers: Dietary interaction and feed additive supplement use. CAB Rev., 1(5): 6.

28. Leeson, S. and Summers, J.D. (2008) Commercial Poultry Nutrition. $3^{\text {rd }}$ ed. Department of Animal and Poultry Science, University of Guelph. Guelph Ontario, Canada.

29. Zhai, W., Schilling, M.W., Jackson, V., Peebles, E.D. and Mercier, Y. (2016) Effects of dietary lysine and methionine supplementation on Ross 708 male broilers from 21 to 42 days of age (II): Breast meat quality. J. Appl. Poult. Res., 25(2): 212-222.

30. Abbas, T.E. (2015) Threonine-lysine ratio and its effects on broiler performance. Int. J. Adv. Res. Biol. Sci., 2(2): 174-179.

31. Awad, W.A., Ghareeb, K., Nitch, S., Pasteiner, S., Raheem, S.A. and Bohm, J. (2008) Effect of dietary inclusion of probiotic, prebiotic and symbiotic on intestinal glucose absorption on broiler chickens. Int. J. Poult. Sci., 7(7): 688-691.

32. Sun, X., McElroy, A., Webb, K.E.Jr., Sefton, A.E. and Novak, C. (2005) Broiler performance and intestinal alterations when fed drug-free diets. Poult. Sci., 84(8): 1294-1302.

33. Fitasari, E. (2012) Penggunaan enzim papain dalam pakan terhadap karakteristik usus dan penampilan produksi ayam pedaging. Buana Sains, 12(1): 7-16.

34. Selle, P.H., Ravindran, V., Ravindran, G. and Bryden, W.L. (2007) Effects of dietary lysine and microbial phytase on growth performance and nutrient utilization of broiler chickens. Asian Australas. J. Anim. Sci., 20(7): 1100-1107.

35. Swatson, H., Gous, R., Iji, P. and Zarrinkalam, R. (2002) Effect of dietary protein level, amino acid balance and feeding level on growth, gastrointestinal tract and mucosal structure of the small intestine in broiler chickens. Anim. Res., 51(6): 501-515.

36. Khan, A.R., Nawaz, H and Zahoor, I. (2006) Effect of different levels of digestibility threonine on growth performance of broiler chicks. J. Anim. Sci., 16: 8-11.

\section{$* * * * * * * *$}

